\title{
Don't ask, don't tell: Canadian policies on radon
}

\author{
Diane L. Kelsall MD MEd
}

See also www.cmaj.ca/lookup/doi/10.1503/cmaj.109-5016

$\mathrm{C}$ olourless. Odourless. Tasteless. A silent killer. These words are commonly ascribed to carbon monoxide gas. But there is another silent killer in our homes. Radon caused an estimated 3000 deaths from lung cancer in Canada last year. ${ }^{1}$ Many Canadians unknowingly live, work or study in buildings with elevated radon levels. There is no requirement in most jurisdictions to monitor for the presence of this deadly radioactive gas, or to mitigate if elevated levels are found.

Radon is produced from the natural breakdown of uranium present in bedrock and soil. Drawn into buildings through cracks, drains and gaps, ${ }^{1}$ radon can build up in enclosed spaces, particularly in the typical Canadian home that is sealed in winter and at night. With a half-life of about four days, the gas breaks down into short-lived products of decay (primarily polonium, as ${ }^{218} \mathrm{Po}$ and ${ }^{214} \mathrm{Po}$ ). When inhaled, these products emit ionizing $\alpha$ particles that interact with lung tissue and begin the sequence of events that can lead to DNA damage and lung cancer. ${ }^{2}$

Exposure to radon accounts for an estimated $16 \%$ of deaths from lung cancer in Canada. ${ }^{3}$ After smoking, it is the second leading cause of lung cancer, and the primary cause of lung cancer in nonsmokers. ${ }^{3}$ The synergistic combination of radon and smoking is particularly deadly. The risk of lung cancer for a nonsmoker by lifetime exposure is 2 in 100 at $200 \mathrm{~Bq} / \mathrm{m}^{3}$ (the upper limit for indoor air currently recommended in $\mathrm{Canada}^{3}$ ), whereas the risk for a smoker is 17 in $100 .^{4}$

No area of the country is radon free. About $7 \%$ of Canadians live in homes with radon levels above the recommended Canadian maximum. ${ }^{5}$ The only way to know if a building is affected is to test for radon over several months - a simple procedure using a kit or monitor. ${ }^{1}$ If elevated levels are found, radon mitigation (e.g., improved ventilation or changes in air pressure differentials) is generally effective. ${ }^{1}$

The federal government has launched a public health campaign to raise awareness of this issue and recommends mitigation whenever the average annual radon concentration in a dwelling or workplace exceeds its recommended maximum. ${ }^{3}$ But there are some serious problems with Canada's approach to this important health issue.

The current maximum in Canada is twice the limit of $100 \mathrm{~Bq} / \mathrm{m}^{3}$ recommended by the World Health Organization (WHO), although strong evidence points to a substantial risk of lung cancer even at this level. ${ }^{2}$ There is no known "safe" threshold for exposure to radon. The dose-response relation is linear, with the relative risk of lung cancer rising by about $10 \%$ per $100-\mathrm{Bq} / \mathrm{m}^{3}$ increase in lifetime exposure. ${ }^{2}$

In addition, there is no requirement in Canada for employers (other than the federal government as an employer), landlords or homeowners to test for radon levels in residential properties, schools, hospitals or workplaces. Furthermore, if elevated levels are found, mitigation is not necessarily required, since following the Canadian guideline is voluntary. If a tenant finds an elevated level of radon in a rental property, the landlord does not have to address the problem. The exceptions are workplaces governed by the Canadian Guidelines for the Management of Naturally Occurring Radioactive Materials, where employers are required to mitigate if radon levels are elevated ${ }^{3}$ however, they are not legally required to test for radon, so the point becomes moot. Mitigation costs money, sometimes thousands of dollars, and there is little incentive for employers, landlords, and homeowners planning to sell a home to test and mitigate, if needed.

We are left in an odd situation in Canada. Drivers and passengers are required to wear seat belts, which are estimated to save about 1000 lives per year. Smoke alarms are required in most jurisdictions, reducing the annual rate of fire-related deaths from 130 per million households by about two-thirds. Yet, the federal government has adopted a "don't ask, don't tell" approach to radon, a proven carcinogen that is ubiquitous and causes thousands of deaths each year.

In this election year, those vying for our votes should take radon seriously. Measures to protect Canadians should include alignment of the Canadian guideline with the WHO's recommendation that exposure be limited to $100 \mathrm{~Bq} / \mathrm{m}^{3}$; mandated prevention, testing and mitigation in schools, hospitals and other public buildings; incorporation and enforcement of radon prevention measures into all building codes $;^{1,2}$ and financial incentives for testing and mitigation through tax credits and subsidized programs for low-income Canadians.

\section{References}

1. Revisiting Canada's radon guideline. Vancouver: David Suzuki Foundation; 2015. Available: www.davidsuzuki.org/publications/downloads/2015/revisiting_canadas_ radon_guideline.pdf (accessed 2015 Apr. 29).

2. WHO handbook on indoor radon: a public health perspective. Geneva: World Health Organization; 2009. Available: http://whqlibdoc.who.int/publications/2009 19789241547673_eng.pdf (accessed 2015 Apr. 29).

3. Radon frequently asked questions. Ottawa: Health Canada; 2014. Available: www.hc-sc.gc.ca/ewh-semt/radiation/radon/faq_fq-eng.php (accessed 2015 Apr. 29).

4. Report of the Radon Working Group on a new radon guideline for Canada. Ottawa: Health Canada; 2006.

5. Cross-Canada survey of radon concentrations in homes: final report. Ottawa: Health Canada; 2012. Available: www.hc-sc.gc.ca/ewh-semt/radiation/radon/survey-sondage -eng.php (accessed 2015 May 1).

Competing interests: See www.cmaj.ca/site/misc/cmaj_staff.xhtml

Affiliation: Deputy Editor, CMAJ

Correspondence to: $C M A J$ editor, pubs@cmaj.ca

CMAJ 2015. DOI:10.1503/cmaj.150503 